\title{
Design and Implementation of Photo Voltaic System with Soft Switched Boost Converter using Analog Fuzzy based MPPT
}

\author{
Mr. N. Ravikumar ${ }^{1}$, Mr. T. Santhana krishnan ${ }^{2}$ \\ I (Power Electronics and Drives, Rajalakshmi Engineering College, India) \\ ${ }^{2}$ (Assistant Professor, Electrical and Electronics Engineering, Rajalakshmi Engineering College, India)
}

\begin{abstract}
Environment friendly solutions are becoming more prominent than ever as a result of concern regarding the state of our deteriorating planet. A new system configuration of the front end rectifier stage for a photovoltaic system is used. Further increasing the solar output voltage is achieved by connecting the soft switched boost converter. The soft switched boost converter converts low voltage dc supply to high voltage dc supply.The inherent nature of the soft switched boost converter to reduce the voltage stress and ripple. The input rectifier stage allows the maximum power point tracking to be used to extract maximum power from the sun when it is available. An analog fuzzy based maximum power point tracking (MPPT) will be used for the photovoltaic $(P V)$ system.
\end{abstract}

Keywords- Analog fuzzy based MPPT, Maximum power point tracking, Soft switched boost converter.

\section{INTRODUCTION}

The photovoltaic (PV) energy has attracted interest as a next generation energy source capable of solving the problems of global warming and energy exhaustion caused by increasing energy consumption. PV energy avoids unnecessary fuel expenses and there is no air pollution or waste. The photovoltaic (PV) array under uniform irradiance exhibits a current-voltage characteristic with a unique point, called the maximum power point (MPP), where the array produces maximum output power. A photovoltaic array is a linked collection of photovoltaic modules, which are in turn made of multiple interconnected solar cells. The solar modules have a long lifetime (20 years or more) and their best production efficiency is approaching $18 \%$. Solar energy can be utilized in two ways: solar heating/cooling and solar electricity. The MPPT is necessary to track continuously the MPP in order to maximize the power output from a PV system, for a given set of operating conditions. Maximum power point tracking (MPPT) method for the photovoltaic (PV) system using an analog fuzzy based MPPT to obtain maximum power. The main advantage of the method is to reduce the steady state oscillation once the maximum power point (MPP) is located. By using soft switching converter to increase the efficiency of converter and reduce the voltage stress. The resulting system has high-efficiency, low cost and very fast tracking maximum power output.

\section{SOLAR CELL MODEL}

A photovoltaic array is a linked collection of photovoltaic module, which are in turn made of multiple interconnected solar cells. The cells convert solar energy into direct current electricity via the photovoltaic effect. The power that one module can produce is seldom enough to meet requirements of a home. Most PV arrays use an inverter to convert the DC power produced by the modules into alternating current that can plug into the existing infrastructure to power lights, motors, and other loads. The modules in a PV array are usually first connected in series to obtain the desired voltage and the individual strings are then connected in parallel to allow the system to produce more current.

The equivalent circuit of a PV module is shown in Figure 1 the characteristic equation for this PV model is given by the equation.

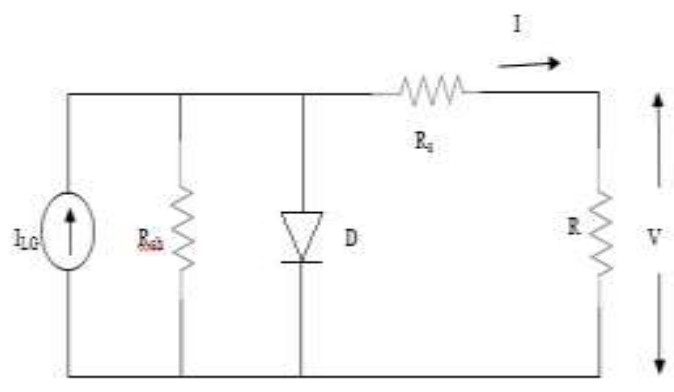

Figure 1. Equivalent circuit of a PV module 


$$
\begin{aligned}
& I=I_{L G}-I_{O S}\left\{\exp \left[\frac{q}{A K T}\left(V+R_{S}\right)\right]-1\right\}-\frac{V+I_{S}}{R_{s h}} \\
& I_{O S}=I_{o r}\left[\frac{T}{T_{o r}}\right]^{3} \exp \left[\frac{\mathrm{qE}_{G O}}{B k}\left(\frac{1}{T_{r}}-\frac{1}{T}\right)\right] \\
& I_{L G}=\left[I_{S C R}+K_{I}(T-25)\right] \lambda / 100
\end{aligned}
$$

Temperature changes affect mainly the PV output voltage. While the irradiation changes affect mainly the PV output current. The intersection of the load-line with the PV module I-V characteristic, for a given temperature and irradiation, determines the operating point. The maximum power production is based on the load-line adjustment under varying atmospheric conditions.

\section{MPPT (MAXIMUM POWER POINT TRACKING)}

For any PV system, the output power can be increased by tracking the MPP (Maximum Power Point) of the PV module by using a controller connected to a dc- dc converter (usually boost converter). However, the MPP changes with insolation level and temperature due to the nonlinear characteristic of PV modules. Each type of PV module has its own specific characteristic. In general, there is a single point on the V-I or V-P curve, called the Maximum Power Point (MPP), at which the entire PV system operates with maximum efficiency and produces its maximum output power.

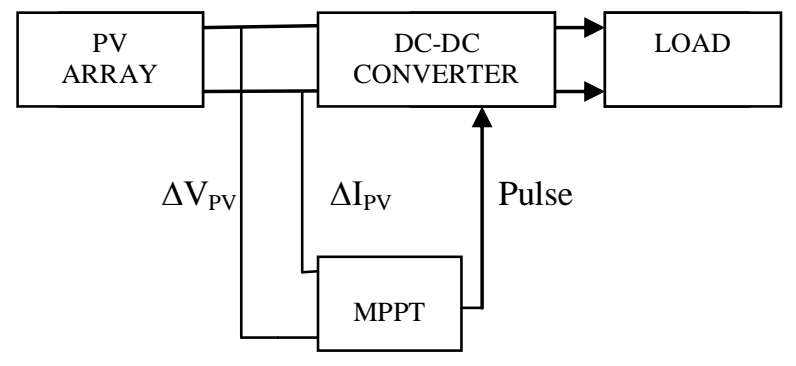

Figure 2. PV system with MPPT

\section{MPPT ALGORITHM}

Various algorithms have been proposed for tracking MPP in the past. Commonly used algorithms are Perturb and observe method, Incremental conductance method, Constant voltage method, Constant Current method etc. The fuzzy logic MPPT is latest and robustness MPP controller. Fuzzy based MPPT controller having fuzzifier, defuzzifier and min-max inference circuits.

\section{METHOD FOR MPPT TRACKING}

Usually MPPT algorithms are based on the comparison of average values of I $p v$ and $\mathrm{V} p v$. The output power can be increased by tracking the MPP (Maximum Power Point) of the PV module by using a controller connected to a dc- dc converter. Each type of PV module has its own specific characteristic. In general, there is a single point on the V-I or V-P curve, called the Maximum Power Point (MPP), at which the entire PV system operates with maximum efficiency and produces its maximum output power.

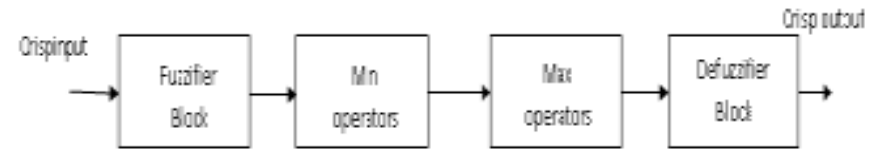

Figure 3. Block diagram of conventional fuzzy min-max network

\section{A. Fuzzifier}

The first stage of a fuzzy set is the fuzzifier block. A Gaussian or triangular membership function is normally used in this step. A membership function of an analog consequent is sampled to discrete grades. A 
membership function circuit which can realize any four types of membership function: S- function, Z-function, trapezoidal function and triangular function using bipolar transistor.

\section{B. Fuzzy inference with min max operator}

The most popular fuzzy logic functions which implement logical "AND" and logical "OR" are MIN and MAX, respectively. The result of the rule evaluation is a fuzzy output for each type of consequent action. The design of min-max circuits using bipolar transistors in the emitter-coupled form.

\section{Defuzzifier}

The centroid or the centre of gravity method is simple and most popular defuzzification method. It is implemented by using the square law MOS characteristics to compute the centroid. It gives high linearity and large dynamic range.

\section{CiRCUit OPERATION}

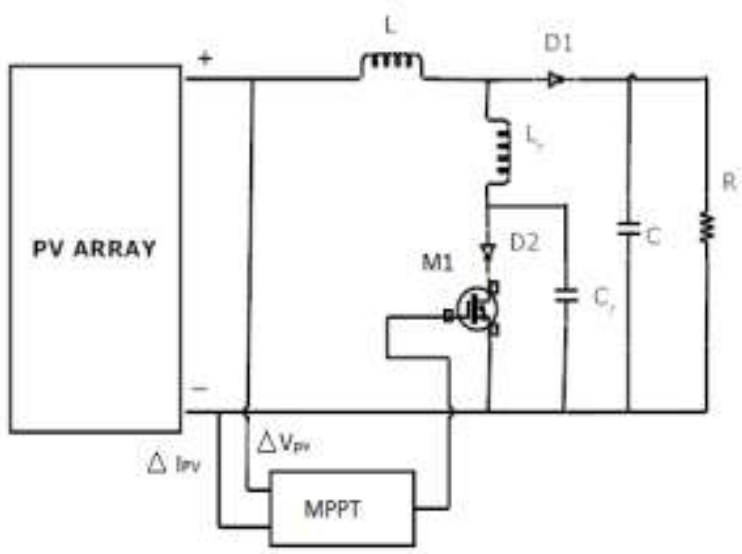

Figure 4. PV system with soft switched boost converter

The basic operation of the analog fuzzy MPPT is based on operating point of the MPP and the average value of the photo voltaic (PV) current rises due to an increase in the reference current. The inputs to the analog fuzzy controller are change in $\mathrm{PV}$ array voltage $\left(\Delta \mathrm{V}_{\mathrm{PV}}\right)$ and change in $\mathrm{PV}$ array current $\left(\Delta \mathrm{I}_{\mathrm{PV}}\right)$ corresponding to the two sampling time instants. The two inputs are processed by the analog fuzzy controller and the output of the analog fuzzy controller is the incremental reference voltage $\left(\Delta \mathrm{V}_{\text {ref }}\right)$. The output of MPPT is given to the comparator, the comparator compares both incremental voltage $\left(\Delta \mathrm{V}_{\text {ref }}\right)$ and reference signal. The comparator output is switching pulse and the pulse is given to the gate of MOSFET(M1). The output of PV is given to the boost converter. During peak power region reduce the oscillation about MPP. Analog fuzzy MPPT tracks the maximum power based on the master-rule.

In every switching cycle, $\mathrm{PV}$ array current $\left(\mathrm{I}_{\mathrm{PV}}\right)$ increases during switching on and decreases during switching off because of the soft switched boost converter. In this operation using boost converter, it converts low input voltage into high output voltage and switching stress also reduced due to soft switching boost converter. 


\section{MODES OF OPERATION}

A. Mode-1 $\left\{t_{0}<t<t_{1}\right\}$

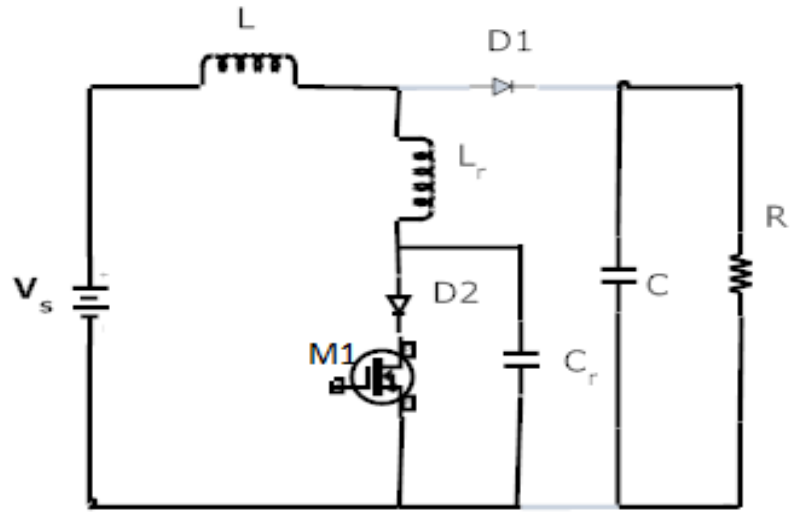

Figure 5. Switch on condition

Prior to this mode, the gating signal for MOSFET M1 from analog fuzzy based MPPT. During this mode the supply current flows to MOSFET M1 and the continuous current does not flows to load but the capacitor gives continuous load current to load. In this mode the ZVS is used to reduce the voltage stress.

\section{A. Mode II $\left\{t_{1}<t<t_{2}\right\}$}

Whereas MOSFET M1 stops conducting, the supply current flows to load and capacitor gets charging.

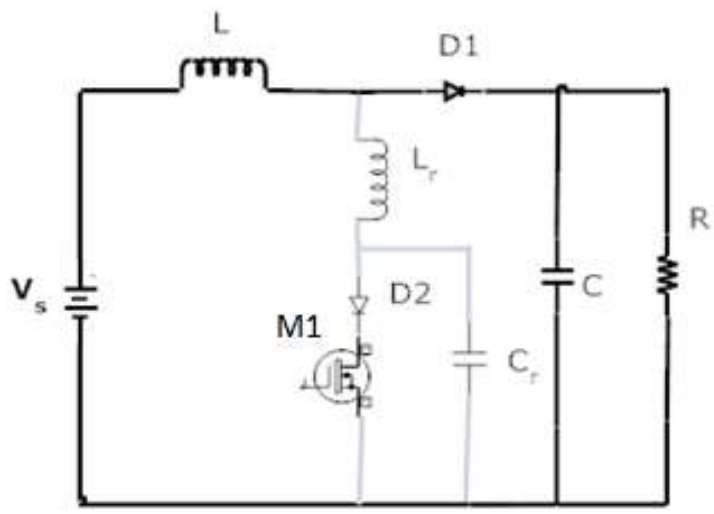

Figure 6. Switch off condition

VIII. Simulation \& RESUltS

The simulation of the PV system was carried out in ORCAD PSPICE software.

TABLE I. Simulation results of switching loss

\begin{tabular}{|c|c|c|}
\hline Condition & $\begin{array}{c}\text { Switching loss for } \\
\text { hard switching }\end{array}$ & $\begin{array}{c}\text { Switching loss for } \\
\text { soft switching }\end{array}$ \\
\hline Initial condition & $18 \mathrm{w}$ & $10 \mathrm{w}$ \\
\hline Peak condition & $300 \mathrm{w}$ & $245 \mathrm{w}$ \\
\hline
\end{tabular}




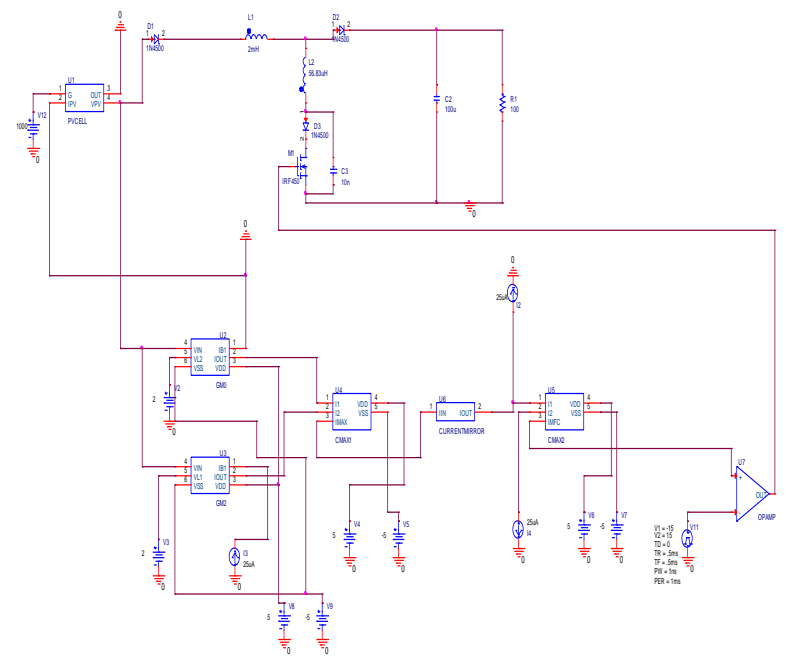

Figure 7. PSPICE model for PV system with soft switched boost converter

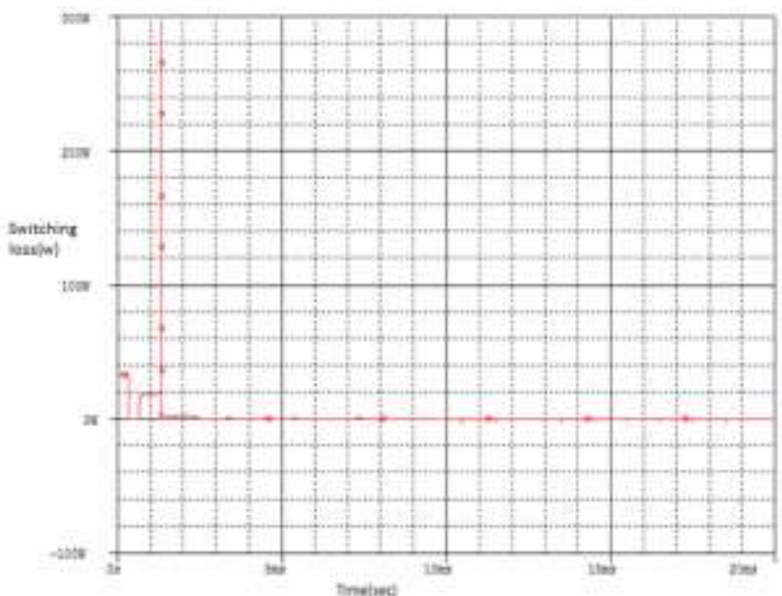

Figure 8. Switching loss for hard switching converter

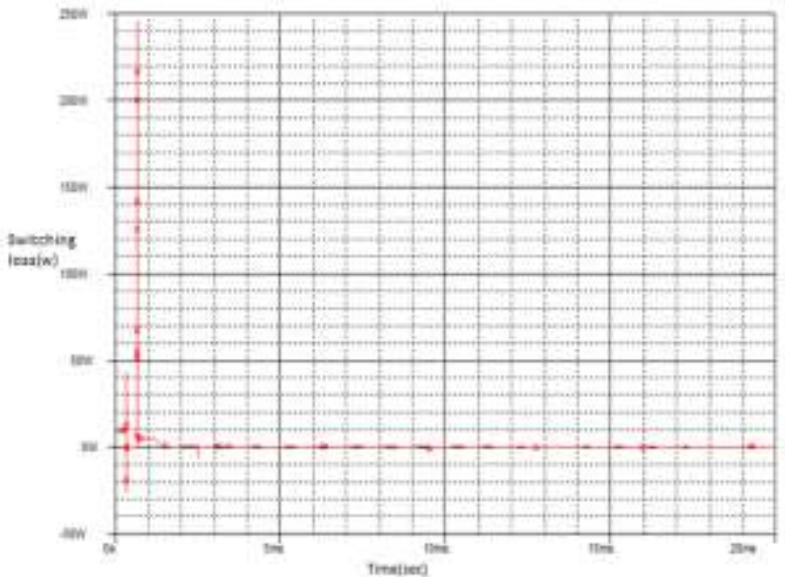

Figure 9. Switching loss for soft switching converter 


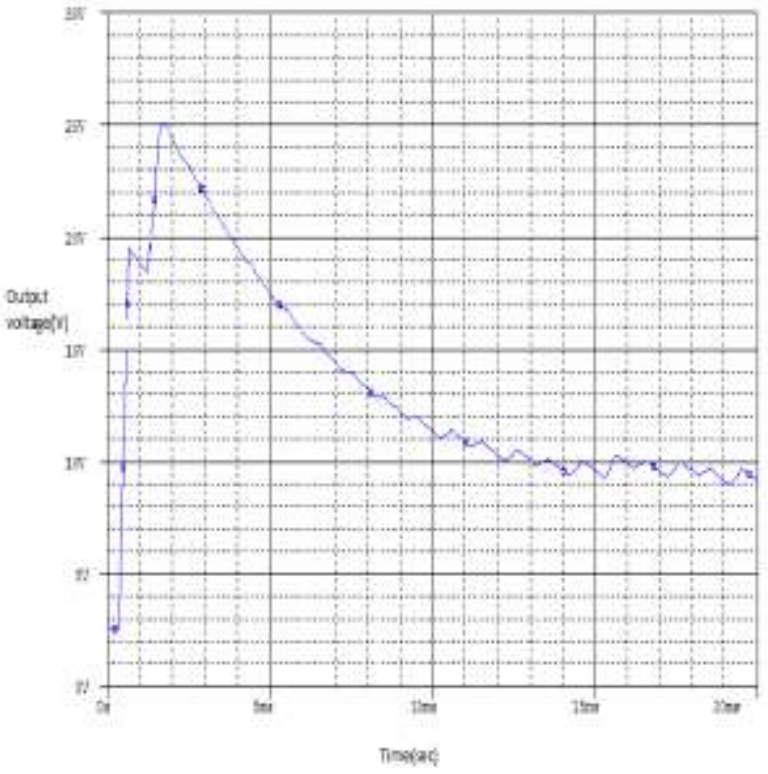

Figure 10. Output voltage of soft switching converter

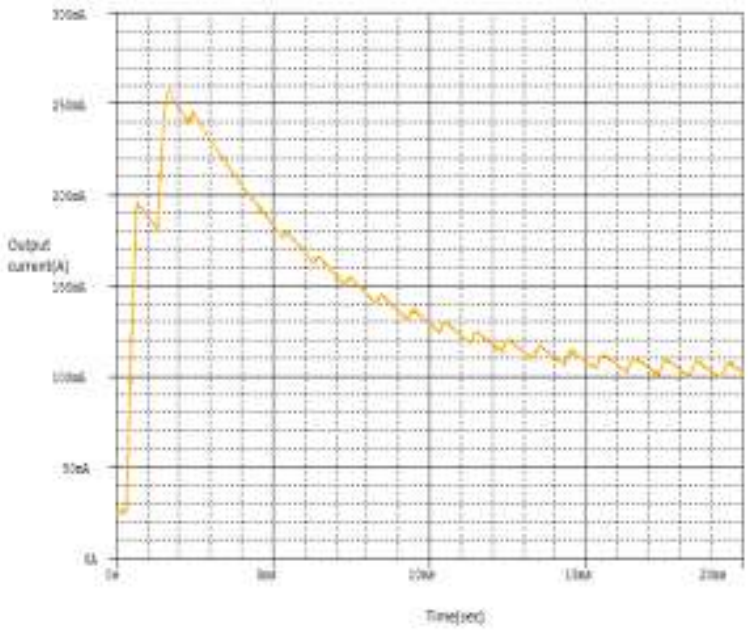

Figure 11. Output current of soft switching converter

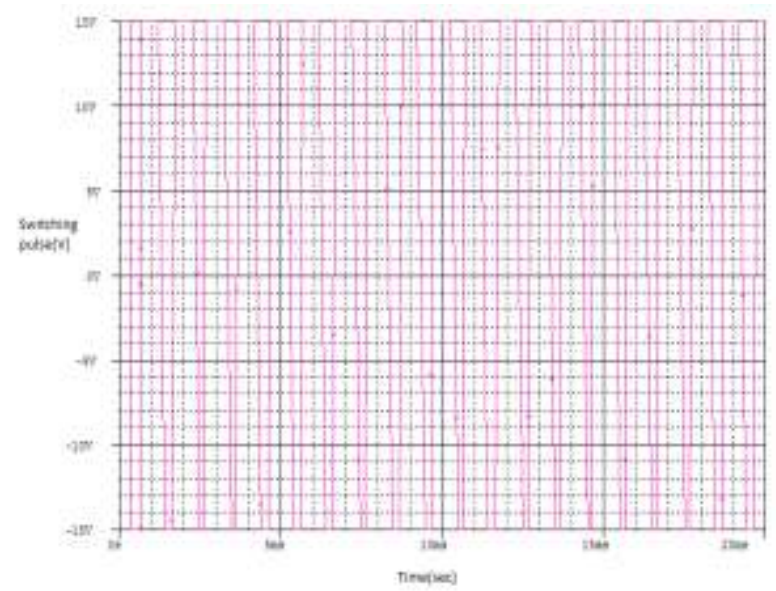

Figure 12. Switching pulse of soft switching converter 


\section{CONCLUSION}

The simulation of the module layout was successfully carried out using ORCAD PSPICE software and the obtained waveforms were observed. The output responses of the soft switched boost converter are analyzed.

The PV array output power delivered to a load can be maximized using analog fuzzy MPPT control. The development of economical power conversion equipment for PV energy will have much impact in the future. The conversion of the output voltage from a solar panel into usable dc or ac voltage has to be done at its maximum power point.

\section{REFERENCES}

\section{Journal Papers:}

[1] Abdelsalam A.K., Massoud A. M., Ahmed S., and Enjeti P. N. (2011) 'High-performance adaptive perturb and observe MPPT technique for photovoltaic-based micro grids' IEEE Transaction Power Electronics, vol. 26, no. 4, pp. 1010-1021.

[2] Agorreta J. L., Borrega M., Lo, pez J. and Marroyo L. (2001) 'Modeling and control of N-paralleled grid-connected inverters with LCL filter coupled due to grid impedance in PV plants' IEEE Transaction Power Electronics, vol. 26, no. 3, pp. 770-785.

[3] Alajmi B. N., Ahmed K. H., Finney S. J. and Williams B. W. (2011) 'Fuzzy logic- control approach of a modified hill-climbing method for maximum power point in micro grid standalone photovoltaic system' IEEE Transaction Power Electronics, vol. 26, no. 4, pp. 1022-1030.

[4] Bangyin L., Shanxu D. and Tao C. (2011) 'Photovoltaic DC-building-module based BIP system-concept and design considerations' IEEE Transaction Power Electronics, vol. 26, no. 5, pp. 1418-1429.

[5] Brunton S. L., Rowley C.W., Kulkarni S. R. and Clarkson C. (2010) 'Maximum power point tracking for photovoltaic optimization using ripple-based extremum seeking control' IEEE Transaction Power Electronics, vol. 25, no. 10, pp. 2531-2540.

[6] Femia N., Petrone G., Spagnuolo G. and Vitelli M. (2005) 'Optimization of perturb an observe maximum power point tracking method' IEEE Transaction Power Electronics, vol. 20, no. 4, pp. 963-973.

[7] Hassan M. A. and Abido M. A. (2011) 'Optimal design of micro grids in autonomous and grid-connected modes using particle swarm optimization' IEEE Transaction Power electronics, vol. 26, no. 3.

[8] Irisawa K., Saito T., Takano I. and Sawada Y. (2000) 'Maximum power point tracking control of photovoltaic generation system under non uniform insolation by means of monitoring cells' Proceedings 28th IEEE Photovoltaic Specialists Conference, pp. 17071710 .

[9] Jain S. and Agarwal V. (2007) 'A single-stage grid connected inverter topology for solar PV systems with maximum power point tracking' IEEE Transaction Power Electronics, vol. 22, no. 5, pp. 1928-1940.

[10] Li Z., Kai S., Yan X., Lanlan F. and Hongjuan G. (2011) 'A modular grid connected photovoltaic generation system based on DC bus' IEEE Transaction Power Electronics, vol. 26, no. 2, pp. 523-531.

[11] Masoum M. A., Dehbonei H. and Fuchs E. F. (2002) 'Theoretical and Experimental analyses of photovoltaic systems with voltage and current -based maximum power point tracking' IEEE Power Eng. Rev., vol. 22, no. 8, pp. 62-62.

[12] Noguchi T., Togashi S. and Nakamoto R. (2002) 'Short-current pulse-based maximum-power-point tracking method for multiple photovoltaic and converter module system’ IEEE Transaction Industrial Electronics, vol. 49, no. 1, pp. $217-223$.

[13] Patel H. and Agarwal V. (2008) 'Maximum power point tracking scheme for PV systems operating under partially shaded condition s' IEEE Transaction Industrial Electronics, vol. 55, no. 4, pp. 1689-1698.

[14] Safari and Mekhilef S. (2011) 'Simulation and hardware implementation of incremental conductance MPPT with direct control method using cuk converter’ IEEE Transaction Industrial Electronics, vol. 58, no. 4, pp. 1154-1161.

[15] Sera D., Teodorescu R., Hantschel J. and Knoll M. (2008) 'Optimized maximum power point tracker for fast-changing environmental conditions’ IEEE Transaction Industrial Electronics, vol. 55, no. 7, pp. 2629-2637.

[16] Serban E., and Serban H. (2010) 'A control strategy for a distributed power generation microgrid application with voltage and current-controlled source converter' IEEE Transaction Power Electronics, vol. 25, no. 12, pp. 2981-2992.

[17] Tse K. K., Ho M. T., Chung H. S. H. and Hui S. Y. (2002) 'A novel maximum power point tracker for PV panels using switching frequency modulation' IEEE Transaction Power Electronics, vol. 17, no. 6, pp. 980-989.

[18] Veerachary M., Senjyu T. and Uezato K. (2002) 'Voltage-based maximum power point tracking control of PV system' IEEE Transaction Aerospace Electronics System, vol. 38, no. 1, pp. 262-270.

[19] Young-Hyok J., Doo-Yong J., Jun-Gu K., Jae-Hyung K., Tae-Won L. and Chung-Yuen W. (2011) 'A real maximum power point tracking method for mismatching compensation in PV array under partially shaded conditions’ IEEE Transaction Power Electronics, vol. 26 , no. 4 , pp. 1001-1009. 